\title{
Archipel
}

ARCHIPEL Études interdisciplinaires sur le monde insulindien

$100 \mid 2020$

Varia

\section{The Sea and Seacoast in Old Javanese Court Poetry: Fishermen, Ports, Ships, and Shipwrecks in the Literary Imagination}

La mer et la côte dans la poésie de cour en vieux-javanais : pêcheurs, ports, navires et naufrages dans l'imagination littéraire

Jiří Jákl

\section{OpenEdition}

\section{Journals}

\section{Electronic version}

URL: http://journals.openedition.org/archipel/2078

DOI: 10.4000/archipel.2078

ISSN: 2104-3655

\section{Publisher}

Association Archipel

\section{Printed version}

Date of publication: 15 December 2020

Number of pages: $69-90$

ISBN: 978-2-910513-84-9

ISSN: 0044-8613

\section{Electronic reference}

Jiří Jákl, «The Sea and Seacoast in Old Javanese Court Poetry: Fishermen, Ports, Ships, and Shipwrecks in the Literary Imagination », Archipel [Online], 100 | 2020, Online since 28 November 2020, connection on 04 December 2020. URL : http://journals.openedition.org/archipel/2078; DOI : https://doi.org/10.4000/archipel.2078 


\title{
LA MER DANS LA LITTÉRATURE JAVANAISE
}

\author{
$J_{I R K I} J_{A ́ K L}^{1}$ \\ The Sea and Seacoast in Old Javanese Court Poetry: \\ Fishermen, Ports, Ships, and Shipwrecks in the Literary \\ Imagination
}

\section{Introduction}

It is well-known that the Malays were and still are excellent mariners. Classical Malay literature, with the earliest texts dating to the late thirteenth century, abounds in descriptions of the open seas, seacoast, communities of fishermen, ships, harbours, and life associated with the early urban environment of ports (Braginsky 2004: 465-77, 681-94). ${ }^{2}$ Though it cannot be doubted that pre-Islamic Java had multiple and complex relations with its close as well as more distant neighbours, maintained long-distance shipping links with South and East Asia, the links that had played an important role in the early state formation in Java (Wisseman Christie 1995), the maritime world and its culture is only poorly reflected in Old Javanese epigraphic record, neither does it figure prominently in Old Javanese literary texts. Scholars of Old Javanese literature have often noted that the world of Java is typically represented as the domain of inland royal courts, religious communities, and peasants, with the economy based on rice agriculture rather than fishing, shipping, and trade (Zoetmulder 1974; Wiryamartana 1992; Worsley 2012). This picture is based mainly on the fragmentary textual evidence that has survived to our days,

1. Institute of Anthropology, Heidelberg University.

2. I would like to thank Pierre-Yves Manguin, who invited me in December 2019 to present some of the ideas discussed in this article at the seminar he teaches in Paris. I am also grateful to Claudine Salmon and two other reviewers for valuable comments on the first draft of this paper, which helped substantially to improve the arguments presented here. 
which has been little concerned with the environment of Javanese coasts and open seas. Our views are certainly distorted for ships and shipping culture do not figure prominently in literary representations of pre-Islamic Java. Yet, there is substantial, mostly Chinese and European evidence that in the fifteenth and sixteenth centuries, and well into the seventeenth century, the Javanese were very active at the seas as shippers and traders who used large ocean-going ships serving the regional and international long-distance trade that linked Southeast Asia with other parts of the world (Manguin 1993, 2012).

In this study I collect and analyse a number of Old Javanese literary vignettes that can further our knowledge about the seacoast and people living in this environment. I will also offer an interpretation of one paradox pertaining to the literary representations of Javanese shipping: why the ships called jon in Old Javanese - which were large ocean-going vessels - are in virtually all literary references predating the fifteenth century associated with shipwreck or other form of maritime mishap. As with other issues discussed in this study, the evidence available to us highly affect the questions that can be asked: the major sources about the maritime environment and the social world of the people living there are not Old Javanese inscriptions but kakawins, Old Javanese court poems in metrical system, a literary genre traditionally considered to be a work of fiction (Zoetmulder 1974). In the last three decades, however, scholars have found ways to appreciate the documentary value of kakawins as a specific historical source for the social, religious, and material aspects of Javanese pre-Islamic culture (Supomo 1995; Hoogervorst and Jákl 2020). Recently, Worsley (2012) has suggested that rather than works of literary fiction, ultimately an early-modern Western construct, Old Javanese kakawins should be understood as a reflection of a sort of "hyper-reality," a complex living experience of pre-Islamic Javanese that links the world of mortals, ancestors, and divine beings in a functional web. This useful concept is also followed and upheld in this study.

Though we hear very little about the open seas and maritime life in Old Javanese kakawins, texts give us some glimpses into the environment of the seacoast and the life of the people drawing their livelihood from marine and coastal resources. These often charming literary vignettes are nevertheless mediated through the lens of court experience: few people at Javanese (inland) courts would have had any direct experience with the open seas, while some level of acquaintance with the coastline might have been widespread. This article develops its arguments in four sections that capture the four major contexts in which the seascape and coasts figure in Old Javanese poetry. First, it is a place where fishermen live, and where gajamina ("elephant fish") can be observed. The coast is also a place where local and foreign ships can harbour and trade their products. Now, it is striking how little we hear about harbours and port cities: there is only one description of a harbour in Old Javanese literature known to me, which is a unique, down-to-the-earth vignette, in 
which we find a glimpse to the port-based prostitution, plausibly the earliest reference we have to this social phenomenon in Southeast Asia. In the second part of this study I discuss a shipping lore, and especially the muddy territory of Old Javanese boat and ship terminology. In the third part I narrow down my focus on one Old Javanese term, jon, and its literary associations with the maritime mishap. In the last section, I shortly discuss the motif of the seacoast as a place of natural and divine beauty.

\section{Socio-Cultural Environment of the Seacoast in Old Javanese Kakawins: Fishermen, Whales, and Ports}

As a starting point, let me introduce a passage reflecting a possibly typical attitude of the Javanese court population to the environment of the seacoast and its social life. In the Sumanasāntaka, a kakawin composed around 1200 $\mathrm{CE}$ by Mpu Monaguna, princess Indumatī has little appreciation for the beauties of the seacoast and its egalitarian society of fishermen:

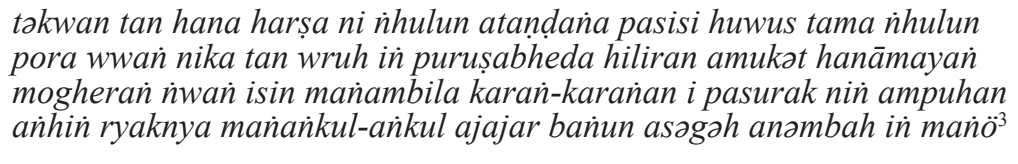

"What is more I take no pleasure in visiting the seaside. I know it well.

The common people there have no regard for difference of rank. They fish with hiliran, pukat

sein-nets, and payain trawl-nets.

So I am ashamed and embarrassed to collect shell-fish in the roaring surf.

Only the waves rise high in rows and appear to welcome respectful poets who are lost in reverie." 4

This passage, though situated in the mythical past, reflects the values of a noble Javanese figure, accustomed to the hierarchical life at Javanese court. Helen Creese (2004) has demonstrated persuasively that for pre-modern Javanese and Balinese women of aristocratic descent, courts were places where they were sequestered, leading a life based on the strict social hierarchy. The description of rugged coast and unrefined manners of the folk living there certainly reflects something of this deep-seated mentality. At the same time, the passage seems to be a self-reference by Mpu Monaguna to his poetic skills: rolling tidal waves would welcome him in a courtly sambah-gesture of humble bow. The rugged seacoast depicted in Old Javanese court poetry has typically been interpreted as a reflection of the rough south coast of Java, where the ocean is deep, the terrain can be difficult, and whales are easy to be spotted (Wiryamartana 1992; Teeuw and Robson 2005: 605). At this locus, poets strive

3. Sumanasāntaka 50.11. Old Javanese text taken from Worsley et al. (2013: 204).

4. Worsley et al. (2013: 205). 
to achieve a kind of aesthetic rapture, denoted laïö in Old Javanese, in which they hope to reach a union with the divinity, often represented by Kāma, the god of love and aesthetic experience. In the state of divine rapture, Javanese kawi would compose poetry and leave his or her verses in the form of graffitilike inscriptions scribbled on a rock or cliff at the seashore. Alternatively, a kawi would jot down verses into a note-pad he carries with him, which might have had a form of a folding notebook made from bark-paper (Jákl 2016). The breathtaking scenery in which the literary activity of Javanese kawis took place is depicted in the Bhomantaka, an anonymous kakawin composed in the late twelfth century CE. In stanza 3.37, prince Sāmba and his military retinue of cavalrymen, tasked with the protection of hermitages, follow the steep path along the cliffs at the seacoast:

luñhā sampun adoh hulih nropatiputra humaliwat i deśa nin pura mārgāgö̈n lamah anggagar hawan irägarihul i salasək nikan watu təkwan koñan ikan pasir sabha-sabhän ikan añapi lan̈ö kasan்huban

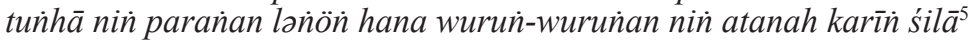

The prince had already left far behind him the district of the capital, And the highway; his path rose into the hills and was bumpy because of the packed stones.

It also overlooked the shore, often frequented by people composing poetry, covered in the mist;

The edge of the cliff was so entrancing that there were unfinished works of those wielding the pen,

left behind on the rocks. ${ }^{6}$

Though the shore is depicted as a desolate place, where only a rambling poet would come to search for beauty, other passages suggest that the south coast of Java was not an uninhabited district. Quite on the contrary, almost all descriptions of the seacoast in Old Javanese literature introduce an image of simple fishermen plying their trade in the coastal waters. At another place in the Bhomāntaka we encounter prince Sāmba and his retinue standing on a high-rising cliff, a locus that certainly supports a view that south rather than north coast of Java served as a literary model for the anonymous author of the text. Like high-rising observation towers at Javanese courts, used in the past for distinguished guests to follow rituals and performances, the cliff offers the men a breathtaking, bird-like view. Standing high above the sea, they observe carefully innumerable canoes of fishermen dotting the seascape:

5. Bhomāntaka 3.37. Old Javanese text taken from Teeuw and Robson (2005: 106).

6. Teeuw and Robson (2005: 107). 


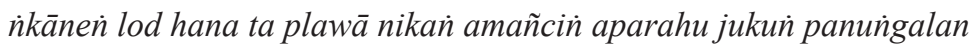
rüpanyāputih an்hulap-hulap apan lumarap i larap in wway in tasik

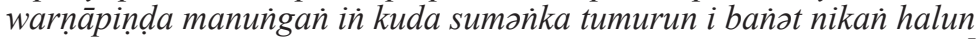
mumbul pwa ṅ gajamīna kāraṇa nikān pañacəpuk awolah maren təpi ${ }^{7}$

Out at sea there were the boats of fishermen, with canoes holding one man each, They looked dazzlingly white, for they glittered in the sparkling seawater; It looked as if they were riding horses, rising and falling on the big waves,

But then a whale surfaced, and so with much splashing they paddled for the shore. ${ }^{8}$

In this humorous vignette fishermen paddle quickly their jukun-boats to the safety of the shore. Old Javanese term jukun is related to Malay jongkong, and in modern language denotes a dugout canoe. It plausibly referred to the same or similar primitive watercraft in ancient Java, too. The motif of the whale (gajamina) that surfaces represents an interesting pun, for in this passage gajamina does not seem to be exclusively a well-known sea mammal. As I have shown elsewhere (Jákl 2014), Old Javanese is rich in terms for large sea mammals, and gajamina (a loanword from Sanskrit that translates "elephant fish") refers in this context rather to a mythological beast, while at the same time it is "just a whale." In my view, the passage is actually a mockery and critique of Sāmba's cavalrymen, young sons of court notables, who are allegorically identified with fishermen in their canoes. To appreciate this narrative strategy, we must come back to stanza 2.10, where the whale (iwak liman) serves as a mythical carrier (wähana) of Bhoma, the king of demons, and eponymous anti-hero of the Bhomantaka. In stanza 2.10 we gather from the report of the venerable sage Nārada that when Bhoma set in the past on his world-conquering campaign, he was riding a huge beast, travelling across the sea.

The identification of Sāmba's cavalrymen with the fishermen, and the gajamina with Bhoma's sea-going mythical carrier, serves as a subtle critique: the moment the whale surfaces the fishermen paddle to the shore for safety, as would later do some of Sāmba's cavalrymen when facing Bhoma's demonic warriors as their enemy.

The seacoast as a domain of fishermen is depicted in other poems, such as the Ghatotkacāśraya, a kakawin composed by Mpu Panuluh in the second half of the twelfth century CE. The vignette in the Ghatotkacāśraya is part of a description of a "pleasure trip" organized by King Kṛ̦ṇa. Courtiers and their servants marvel over the beauty of the coast:

7. Bhomāntaka 3.42. Old Javanese text taken from Teeuw and Robson (2005: 108).

8. Teeuw and Robson (2005: 109). 


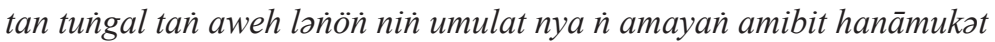

lìlā tan hana rosnya riñ wway $i$ domit ni parahu niki lüd pad̄aggalin

mosyan himpar aburwa-burwan anərah sakayapu kalilī $n$ huwus lopas

lwir mukșen் təpi nìn lanit kahiḍpanya hilan் anusup in ghanāhirən் $\dot{n}^{9}$

There were various things that enchanted the watchers: see, the people fishing with trawl-nets,

with line and hook, and still others with seine-nets,

At their ease, without fear of the water, seeing the slenderness of their boats, all equally unsteady,

Bustling to and fro as if pursuing each other out to see, like aquatic flowers swept along by the

current, for they were already well on their way,

And if dissolving into the horizon, one would think, disappearing into the black clouds. ${ }^{10}$

The passage quoted above depicts fishermen in their boats, denoted parahu in the text, who catch fish with at least three types of fishing-tack. Mpu Panuluh marvels at the dexterity of the men: unlike a simple fishing rod and undemanding method of fishing with the line and hook, the use of seine-nets (pukat) and especially trawl-nets (payain) requires a high degree of cooperation between several boats, and a great level of skill and experience at the side of fishermen. The poet also appreciates fearlessness the men demonstrate: at least some of them are engaged in catching lobsters and giant-crabs at the reefs, which can be even today a life-endangering business. Though paddled jukun canoes might have been the most common type of fishermen's vessels in pre-modern Java, in Old Javanese epigraphic record we also encounter boats propelled by poles. Rather surprisingly, such references are rare in extreme, at least according to the interpretations of Old Javanese boat terminology offered so far. Shallow boats propelled by poles (galah) are mentioned in at least one Old Javanese epigraphic document: in the Turyan inscription, issued in 929 CE by Sindok for the benefit of a certain Dan Atu Pu Sāhitya. ${ }^{11}$ In this inscription parahu magalaha ("boats propelled by poles") are mentioned (de

9. Ghațotkacāśraya 8.5. Old Javanese text taken from Robson (2016: 70).

10. Robson (2016: 71).

11. Old Javanese galah has a number of meanings, but the basic meaning of this term is "spear, lance." In his extensive gloss on galah, Zoetmulder (1982: 477-78) does not consider "pole" among its meanings, though the Turyan inscription leaves no doubt that galah indeed denoted pole used to propel punts, which it still does in modern language. The problem of poles used to propel boats is complex. In Malay poles are called galah prahu, and galah is also attested in this sense in Madurese and Balinese. I leave open a possibility that boats propelled by a pole or poles are covered by the Old Javanese term masuinhära. Zoetmulder (1982: 1856) glosses sunhar as "part of a boat (mast?)." But the fact that most of these crafts mentioned in Old Javanese inscriptions seem to have operated inland, either on rivers, lakes, or dams, would point at simple boats rather than sailing vessels. 
Casparis 1988: 45). ${ }^{12}$ The inland location of the inscription, found still in situ in the rice-fields of the village of Turen, some 15 kilometres southeast from Malang, indicates that such boats were used on shallow waters. ${ }^{13}$ Apart from fishing boats propelled by poles or paddles, we also encounter fishing vessels using sails, for example in Ghațotkacāśraya 8.6, where we find a reference to the "sails of the fishermen who use the trawl-nets" (layar in amayan்).

While images of fishermen and fishing are not rare in Old Javanese literature, depictions of harbours and port urban sites are almost non-existent in kakawins. This anomaly is even more striking when we consider how common literary depictions of ports and harbour communities are in classical Malay literature (Manguin 1996; Braginsky 2004). Here I would like to introduce a rare Old Javanese literary vignette in which a harbour and some aspects of the life in port are depicted. The vignette is found in the Bhomantaka, in stanzas 6.8 to 14 . The harbour, denoted palabuhan in stanza 6.11, is called Anartha, as we gather from stanza 6.8. It is located at the river delta, and its entry point is overseen by a high-rising tower, denoted waruga in the text. The term has many parallels in Indonesian languages, and in the Bhomāntaka it seems to refer to a kind of watch-tower or lighthouse to monitor approaching ships. We gather this from stanza 6.11, where the waruga is called "observation tower" (paniunan்). Teeuw and Robson (2005: 609) have noted that in Sumatra and Sulawesi, waruga often refers to a kind of lodging used in the past by travelling state officials. Prince Sāmba and his military retinue pass Anartha on their march to the mountains, arriving at the port at the day of Logi, when a great market is held there. We can only guess the reason why the military party visits the port, possibly the men were in need to restock on food supplies and fodder for horses, but the text is silent on the actual cause of their visit. In the market, "they found warehouses in succession, arranged in rows, not to mention single stands" (kambah asarik racana ni pajajarnya len topas), as we learn in stanza 6.11. Next, in stanzas $6.12-13$, the anonymous author of the text offers us a description of female alcohol vendors, who double at the same time as prostitutes. Let me quote an excellent translation of the two stanzas by Teeuw and Robson (2005: 129):

12. Turyan A.18-19. The boat is further specified as having no tundan (tanpa tundāna), which further emphasizes a rather simple structure of this type of boat. For the meaning of Old Javanese tunda, see the discussion below.

13. The inscription informs us that part of the bwat haji (obligatory labour for a lord) of the villagers of Turyan was transferred to a sacred barrage, a dam which was built to hold back the waters of the stream (de Casparis 1988: 40). It is tempting to speculate that the boats propelled by poles mentioned in the text were used at the shallow waters of the dam. 


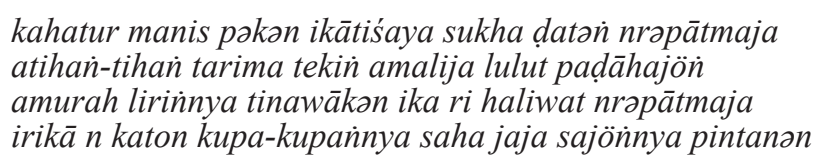

masuhun-suhun səkar ikan parawan ajaja künnya kañlihan mawade hayunya ri harəpnya hañañan ira sañ nrəpātmaja mwañ apan்kwa-pañkwana təriahnya man்usira təwas karäsikan lalu kāsihanya tuna künnya manaḍah-asihen kuran walas ${ }^{14}$

It happened to be the day of Ləgi, and the market was exceedingly happy at the Prince's coming:

The traders in love, equally pretty, were making ready to receive him;

Cheap were the glances they offered as the Prince passed by,

And then their kupan-shells could be seen, together with their sweets and palmwine for the asking.

Carrying flowers on their heads, the ladies paddled their love languidly, Offering their beauty for sale, in the hope that the Prince would carry them off, Would take them on his lap and embrace their waists in order to seek the profits of the delights of love. ${ }^{15}$

Teew and Robson (2005: 609) have noted a pun in the use of the term kupan, which refers to a kind of shell, which shape is suggestive of female genitalia. Moreover, "the kupan shells" of women vendors that could be seen (katon kupakupaninya) is a double allusion to sexual availability of these female vendors provided on top of selling alcohol and snacks. More precisely, the term kupan denotes a class of marine molluscs or its mussel, which were put to use in some parts of pre-modern world as a weight-value unit. In pre-Islamic Java, moreover, kupan denoted a type of coin. The term probably derives from the cup-shaped flan of the coin that resembles the mussel. Zoetmulder (1982: 928) claims that Old Javanese kupan refers to a "shell used as money" but Wisseman Christie (1996: 260) rightly observes that the use of this term for a small currency unit does not indicate any early use of shells as currency in Java. In ancient Javanese monetary system there were four kupain in one māsa, and each kupain weighing about 0.6 gram. The kupan weight was associated both with gold and silver in Old Javanese inscriptions, although Wisseman Christie (1996: 260) observes that no gold coins of this weight have as yet been reported from Java. ${ }^{16}$ To summarize, by the time Bhomāntaka was composed, kupan denoted coins which were commonly used in market transactions. To the best of my knowledge, this twelfth-century vignette gives us, though in the form of a literary metaphor, the earliest description of port-based prostitution in Southeast Asia.

14. Bhomāntaka 6.12-13. Old Javanese text taken from Teeuw and Robson (2005: 128). 15. Bhomāntaka 6.11-13.

16. See also van Aelst (1995: 357-93) for the history of low-value coins and coinage in Java. 


\section{Boats and Ships in Old Javanese Kakawins: A Few Notes on a Complex Terminology}

The seacoast, of course, is also the place where diverse types of boats and ships can be seen. Old and Middle Javanese language is rich in words denoting watercrafts and their structural elements, though many of these terms are not fully understood (Setianingsih 1993; Barrett Jones 1984: 39-42; Prihatmoko 2014: 162, 167-68). Unlike sea-going vessels, riverine crafts, which were certainly a common sight in pre-modern Java and are often mentioned in inscriptions, figure in Old Javanese literary texts very rarely. In the epigraphic record, in particular in the inscriptions of Siṇdok and Airlanga, riverine crafts are typically listed as means of taxable transport. The men who operated these vessels figure among the category of full-time professionals (samwyawahära), along with other professional transporters, such as the men who hired out pack animals, carts, and wagons (Wisseman Christie 1998: 350). Frequent inscriptional references to riverine boats, especially in the context of intervillage trade, indicate that the villages concerned must have been on navigable rivers. The terminology of riverine crafts (and vessels operated in river deltas and coastal waters) mentioned in Old Javanese epigraphic corpus is complex and often difficult, but a detailed analysis of the data would certainly bring new evidence about the economic and social life of Java before $1500 \mathrm{CE}$. Barrett Jones (1984: 40) has noted the richness of boat and ship terminology in her brief discussion of the Bimalāśrama inscription, an undated charter issued for the benefit of a Buddhist monastery of Bimalāśrama. ${ }^{17}$ In a long list of water vessels she has counted staggering twenty-nine types of boats and ships. Though many of these terms refer to an "economic type" of the vessel (what kind of commodity it carried), the inscription is a treasure-trove of Javanese pre-modern boat names and shipping lore.

We have seen above that the vessels used by fishermen were sometimes provided with sails. Larger ships, such as bahitra, jon, palwa, pəlain, and sampo seem to have been equipped with one or more canted rectangular sails. Depictions of water vessels at Javanese temple monuments also indicate that larger ships were provided with two sails. Borobudur, in particular, is rightly famous for its technically sound depictions of at least eleven water crafts; apart from sails, reliefs show details of outriggers, rowing configurations, rigging elements, and rope use. These visually striking depictions have been mined by a number of scholars as a source for the history of ships and ship-building in Southeast Asia, though the debate has mostly focused on five outrigger vessels

17. The inscription has been misread and misnamed as the Dhimalāśrama inscription (Barrett Jones 1984: 44; Wisseman Christie 1998: 372; Hedwi Prihatmoko 2014). Recently, Arlo Griffiths has suggested, drawing on evidence in a short inscription from Dieng in Central Java, that the correct name of the monastery for whose favour the charter was issued is actually Bimalāśrama (personal communication). 
with canted rectangular sails, bipod masts and rowing galleries (Jahan 2006; Manguin 2010). Old Javanese literary evidence, on the other hand, has been only rarely used as a source by historians. Yet, a careful reading of several passages can support visual evidence, and even provide some new insights. For example, visual evidence of temple reliefs that two sails were used on Javanese trading ships seems to be supported by a passage in Bhomāntaka 4.1, where we encounter the phrase layar nin banyagga ("the sails of a merchantship"). By way of metaphor, the author likens the sails to the breasts (anusunusu) of a maiden (kanya) ), which seems to indicate that (typical) merchant vessel was provided with two sails. The same phrase (layar nin banyagga) is attested in Sumanasāntaka 51.2, where we learn that "the sails of a merchant ship, following the wind, head off into the distance like mist" (layar nin banyāgānutakən anin andoh kadi limut).

Very interesting are references to ships denoted bahitra. The word is a loanword from an Indian source. Zoetmulder (1982: 188), for one, glosses bahitra rather generally as "boat, vessel," which is the meaning of this word in Sanskrit. In my view, we can be more precise about the type of ship denoted bahitra in Old Javanese. Literary references indicate that bahitra was a large, ocean-going ship, which was probably owned and operated by foreigner mariners. In the Smaradahana, a kakawin composed by Mpu Triguna in the twelfth century CE, bähitra refers to a large, ocean-going vessel that is said "to be heading to Java" (manajawa). ${ }^{18}$ An interesting literary vignette in the Sumanasāntaka can help us to specify the type of the ship denoted bahitra in Old Javanese texts. It is found in stanza 33.4, which depicts the arrival of prince Aja and his retinue at the seashore. From the coastline the men can see three types of watercrafts, which are compared by way of an extent metaphor to three kinds of animals. Two of them are local birds, while the third animal is a "foreigner," a non-native visitor:

mambö sāgara ramya nin lanit awarna tali hurut-urutnya tan pagat

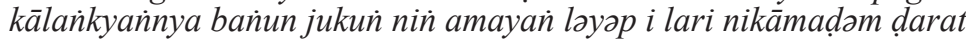
kuntul mör kadi tunḍan in banawa kāri tan ilu kajahat lanālayar

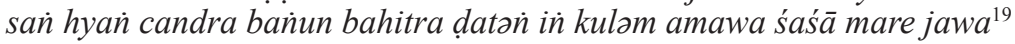

The beautiful sky gave the impression of the ocean: the unbroken threads of clouds were

like fishing lines [of fishermen],

The kälankkyan-bird was like a canoe of the fishermen who use the payan-nets, disappearing from view when its course headed for the shore.

The heron in flight resembled the tunda of a banawa-ship that - safe from shipwreck -

18. Smaradahana 5.12 .

19. Sumanasāntaka 33.4. Old Javanese text taken from Worsley et al. (2013: 166). 
continued to sail.

The holy moon was like the ocean-going bahitra, coming in the night, carrying the hare as its

cargo to Java.

In a brilliant metaphor, Mpu Monaguna depicts the sky and the sea as if being inverted and merged together. The world of the sky above the seacoast, with its clouds, birds, and the moon, turns into a sea-space where fishermen in small boats work their nets, and larger merchant ships ply their business. This charming vignette is one of a number of passages found in the kakawin poetry, which are based on an image of the inverted, topsy-turvy world, a concept that can be traced to the Tantric lore, and which is related to the Balinese esoteric practices of visualizing and embodying Ongkāra Ngadəg and Ongkāra Sungsang. This is, however, not a place to go in details on this topic. Now, in the stanza quoted above, three types of vessels on apparently different size and type are introduced: jukun used by the fishermen, a larger banawa-ship, which is characterized by the presence of tunda(s), possibly some type of superstructure (or outriggers?), and an ocean-going trading vessel denoted bahitra in the text. Interestingly, the jukun and banawa are associated with the native species of birds, while the bahitra is not. In my view, this narrative device can be read as a meta-poetical commentary on three distinct types of watercraft. Old Javanese jukun refers to the canoe propelled by paddling, which is metaphorically associated in this passage with the kalankyan. I will demonstrate in a study that is still under preparation that Old Javanese kalainkyan-bird should be identified as the White-bellied Sea Eagle, a bird native to Southeast Asia, which feeds mostly on fish and sea snakes. As fishermen catch fish with trawl-nets, the kalankyan-bird seems to be hunting for fish at the seashore. The banawa-ship, associated with the heron in flight, is certainly a larger watercraft than a simple canoe, as the heron would be a larger bird than the kalankyan. As for the bahitra, it is not associated with any native bird, but rather with a hare (śaśa), which it brings as its cargo to Java, as we learn in the last line of the stanza. This is, of course, a poetic trope wellknown in Sanskrit literary discourse. In my view, the bahitra-ship would also be a "foreign species," so to say, an ocean-going ship owned or operated by foreigner mariners, possibly Indians.

\section{Shipwreck in Old Javanese Court Poetry: Why Junks always Wreck?}

As elsewhere in the maritime world, not all ships made it safely to the port. Numerous shipwrecks found in the Indonesian waters indicate that marine mishaps were the occasional dark side of the business. Probably unsurprisingly, vignettes of marine mishaps found in Old Javanese court poetry almost always represent shipwreck in a figurative sense, as a metaphorical vehicle to illustrate some other theme. Such figurative uses of the shipwreck motif 
have a very long history, stretching back to antiquity (Thompson ed., 2013). In Javanese and Malay texts, the ship is sometimes construed as a metaphor for the larger community from which it hails, and the same is true for a metaphorical description of shipwreck. One of the most interesting vignettes is found in Kakawin Rāmāyaṇa 22.29-33, where the demon king Rāwaṇa is likened to a wrecked ocean-going sambo-ship, which is described in five stanzas of the text. Old Javanese sambo is most probably a loanword from Old Malay, where we find the form sämwau, a word which may be related to modern Malay sampan, the term well-attested in classical Malay literature in the sixteenth and seventeenth centuries. The origin of Old Malay sämwau and Old Javanese sambo terms is a complex issue, and we have little idea what the actual referents of these words looked like. Boats denoted in Old Malay sāmwau must have been substantial ocean-going water crafts, but the Kedukan Bukit inscription is silent about the type and form of these vessels. ${ }^{20}$ Cognates in a number of Southeast Asian languages seem to imply that Malay (in particular Śrivijayan) shipping culture and Old Malay nautical lexicon must have been influential in the Indian Ocean. ${ }^{21}$ The ultimate origin of Old Malay and Old Javanese terms, however, may go back to the shipping lore of Funan mariners, who connected Southeast Asia with littoral China and South Asia already in the first half of the first millennium CE. Porée Maspero (1986: 80), for one, has made a link between Old Malay sämwau and a very old Chinese loan - pronounced buk 舶 and by now bo, which first appeared in Chinese record in the third century CE, when it referred to large ocean-going vessels. As suggested by Claudine Salmon (2019: 25), the term may have first belonged to a language now lost to history. ${ }^{22}$

20. Boats denoted sāmwau are first mentioned in the Old Malay Kedukan Bukit inscription, issued in $685 \mathrm{CE}$, where we learn that sāmwau carried Srīvijayan military troops to the reaches of the Musi river. Another Old Malay epigraphic document, the Kota Kapur inscription, issued by the same ruler in $686 \mathrm{CE}$, does not mention any specific name of boat, but the finding site of this epigraph on the island of Bangka (apparently conquered by Śrivijaya) implies that boats of some sort must have been used in the Śrivijayan military campaign. Furthermore, the Kota Kapur inscription informs us that the army of Srivvijaya had conducted a military expedition against Java. Of course, any army dispatched from Sumatra or Bangka island to Java could only have proceeded by sea.

21. Manguin (2012: 171, n. 12) has suggested that the broad coverage of cognates of Old Malay sāmwau is most probably related to Śrivijaya's considerable outreach in the seventh to thirteenth centuries CE. Pre-modern shipping technology and maritime lore of Śrivijaya must have been influential for cognates of sāmwau are found in a number of Austronesian languages, and the word even passed to Austroasiatic, TibetoBurman, and Thai languages. In Old Khmer it is called samvau, which becomes sambau in modern Khmer (Pou 1992: 488).

22. Large ships were built in China as early as in the Han dynasty, as is suggested by the find of a shipyard at Guangzhou dated to the third to second century BCE, where 
The passage in the Kakawin Rammāyana, to which we now come back, can further our knowledge about the boats denoted sambo in Old Javanese, and sāmwau in Old Malay. In the speech delivered shortly before Rāwana's death, his younger brother Kumbhakarna likens him to a wrecked sambo. In stanzas 22.32-33, the structural elements of sambo are said to be defunct and/ or destroyed, and likened to Rāwanna's bad character: a rotten keel is said to be Rāwaṇa's lack of knowledge, smashed masts are compared to his broken devotion, torn and tattered sails are his immoral behaviour, and destroyed rudders are Rāwana's lack of loyalty. As I read this literary vignette, it offers a window into the construction of the sambo-boat as it was known to an anonymous Javanese author of the text around 900 CE. The ship had one or more masts (tihan) provided with sails (layar). ${ }^{23}$ The meaning of kawuntat is unclear, but Robson (2015: 580) has interpreted it as "rudder." The keel is denoted lunas, which is still the term for ship's keel in modern Javanese. Now, the context of the ocean where the ship is said to be wrecked, and a reference to bhānda ("merchandise, cargo") in stanza 22.33, which is likened to Rāwaṇa's virtues (dharma), and said to be "vanished" (lonit), clearly suggest that the sambo envisaged by the poet is a large, ocean-going merchant ship..$^{24}$

Javanese gentry living at inland courts, a typical audience of the kakawin poetry, seem to have understood well the nuances of ship terminology, and courtiers were certainly able to decode metaphors based on the ship-lore, for much of the international imports (which arrived as cargoes on oceangoing ships) were used and redistributed by the inland courts. In my view, the same method of analysis of "metaphorical marking" can be applied to another, much better known ship term: join. Old Javanese jon is usually taken to be an Austronesian word rather than a loan from a non-Austronesian

\footnotetext{
ships up to 30 meters in length were constructed (Schottenhammer 2012: 66). The term $b o$ has been used in a number of compound words to denote sea-going vessels. Claudine Salmon (2019: 25), who has recently discussed this term in some detail, notes that the compound form bochuan, which designates a 'sea-going vessel', occurs already in the Huayang guozhi 华阳国志 ("Records of the Countries to the South of Mount Hua"), a text dated to the fourth century CE.

23. Kakawin Rāmāyana 22.32. Old Javanese layar can be traced to its ProtoAustronesian form *layaR, and cognates of layar for sail are known to have spread widely across the Pacific and the Indian Ocean, as they are found in a number of South Asian languages, the Maldives, and, of course, in Malagasy of Madagascar (Hoogervorst 2013: 202).

24. I can come up with only one solution why the author of the Kakawin Rāmāyana selected Old Malay loanword, which is very rare in Old Javanese, to refer to the ship that wrecks, and represents thus Rāwana's doom: Rāwana, who on the metaphorical level represents in the Kakawin Rāmāyaṇa the Buddhist Sailendra dynasty, ousted in the mid-ninth century from their Javanese territories, is associated with the Malaytype vessel, sambo, and hence with the Malay Śrivijaya kingdom, an economic and political competitor of the Javanese Sañjaya dynasty.
} 
source. Zoetmulder (1982: 748), for one, glosses joi as "(sea-going) ship." Manguin (1980,1993), who has analysed in detail the evidence we have for this type of ship, has demonstrated that junks were large (often very large), ocean-going ships operated by Southeast Asian mariners, especially Javanese and Malays. When the first Portuguese visitors encountered Javanese junks in Southeast Asian waters, junks were mostly used to transport high-volume commodities, such as rice and timber, among the ports of Southeast Asia and beyond (Manguin 2012). The earliest reference to Old Javanese jor is attested in eleventh-century Balinese inscriptions, ${ }^{25}$ and the first literary reference to $j o \dot{n}$ is in the Bhomantaka, a court poem composed in the late twelfth century CE. Most interestingly, the jon figures in all Old Javanese literary references in the context of shipwreck, which is, as we have seen above, associated in Old Javanese literature with the forces of adharma. In the Bhomantaka the reference occurs in the framework of a joyful celebration of gods, who arrive to congratulate King Kṛșna for his victory over the demon king Bhoma. In stanza 109.3, Waruna, called in the text "Lord of the Waters" (toyādhipati), and "God of the Waves" (sain hyan ryak), is particularly elated when Bhoma is killed in the battle. Let me quote the relevant passage:

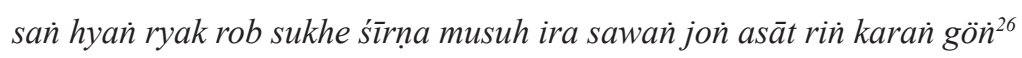

The God of the Waves was at the high tide of his happiness that his enemy had been shattered like

a jon run aground on a great reef.

Another reference to jon is found in the Arjunawijaya, a kakawin composed by Mpu Tantulār in the second half of the fourteenth century. In stanza 8.11, we learn that "the joris and pelan-boats wrecked and sank down" (jon pelan tan $d$ wa binkas karzm). ${ }^{27}$ The third passage in which jon-ships figure is found in the Sutasoma, another work by Mpu Tantulār, where we have a vivid description of a march of demonic troops of the cannibal-king Poruśăda to the battlefield. Some of his warriors move on the ground, while others fly through the air. Still other troops use the sea to reach the battlefield. The Three Worlds (triloka) suffer in this complex military operation, as we gather from stanza 114.11, where Mpu Tantulār depicts the havoc demonic troops cause:

25. I am grateful to Pierre-Yves Manguin for noting me that the term jon is attested in the Balinese epigraphic corpus already in the eleventh century $\mathrm{CE}$, while the first literary reference can be traced to the late twelfth century CE.

26. Bhomāntaka 109.3c. Old Javanese text taken from Teeuw and Robson (2005: 581).

27. Arjunawijaya 8.11. The passage is part of a long description of a havoc in the world of men caused by the war between the divine forces of dharma and demonic forces of adharma. The sea is in tumult, and as a consequence many ships wreck. 


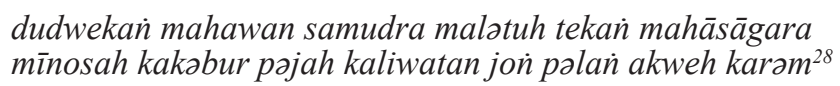

Still other (troops) moved across the impure waters of the great ocean;

The fish tossed and turned, stirred violently they died, and many of the junks and polan-boats passing over the sea sank down.

It seems to me that Mpu Tantulār uses the motif of wrecked jori(s) in two of his texts like a set phrase. Apart from Old Javanese court poetry, ships denoted jonis are associated with the maritime mishap also in the Middle Javanese text Ranga Lawe, a kidun that may have been composed as early as the fourteenth century CE, but which final redaction postdates 1500 CE (Zoetmulder 1974). We learn in stanza 8.37 that its broken, malfunctioning rudder (kamodi) is the reason why the jon wrecked (jon kuran kamodyanulus karzm). ${ }^{29}$ The negative associations of jon with the shipwreck - what seems to have been a wellknown literary cliché - calls for an explanation. I can only think about one reason why jor is stigmatized in Old Javanese court poetry: ships denoted jons must have been associated with the shipping of Javanese port enclaves of the north coast of Java (pasisir), districts which were never under the complete control of Javanese rulers, who were based at inland courts. As early as the twelfth century, jons might have been associated with the growing economic and possibly political power of the pasisir administrators and local lords, who were approached with distrust by Javanese inland royal courts. This finding would fit the model according to which Late Kadiri period (ca. 1100 to 1222 $\mathrm{CE}$ ) was a time of increased social tensions between the well-established, inland and agriculture-based Javanese courts, and the growing power of new merchant elites, who were active in the international shipping and trade with luxurious goods, especially Indian textiles and Chinese stoneware and porcelain (Jákl and Hoogervorst 2017). We lack evidence, however, that these tensions would have developed into a full-fledged military conflict between the two zones. Recently, Victor Lieberman (2009: 780) has noted in his discussion of pre-Islamic Java that "despite tensions between mercantile coast and agrarian interior reminiscent of conflicts in Burma and Angkor, for long periods before 1500 Java succeeded in wedding the two spheres under a single authority."

Shipwreck is a rare literary motif in Old Javanese poetry, which has been noted, but largely uncommented, by previous scholarship (Zoetmulder 1974; Wiryamartana 1992; Worsley et al. 2013). The motif has a narrative parallel in much more common depictions of ruined temples and monasteries. Recently, Stuart Robson (2012) has discussed the motif of architectural ruins in a stimulating study, noting that the image of collapsed temples, monasteries, and hermitages, overgrown with lush vegetation, is a literary trope that is distinctly

28. Sutasoma $114.11 \mathrm{~cd}$.

29. Ranga Lawe 8.37. 
Javanese, and has no exact parallel in Sanskrit kāvya poetry. Interestingly, Old Javanese descriptions of wrecked ships and collapsed temples display one common feature: they are often eroticized. In my view, the motif of a wrecked ship is an allusion on a painful separation of lovers. Let me introduce a vignette in the Sumanasāntaka, in which collapsed masts (tihañ) of a ship (banawa) remind Mpu Monaguna of a pair of lovers, who embrace one another, unable to part:

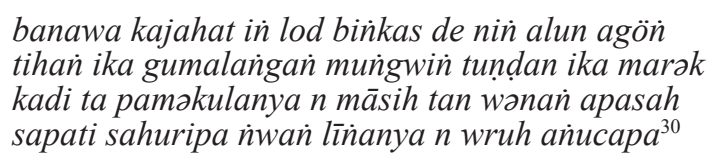

A banawa-boat wrecked at sea had been smashed by great waves.

Its [collapsed] masts were propping one another, positioned at the fore of the tundan;

As if being embraced, as lovers do when they are unable to part:

"In death and in life I will remain with you", they might have said if they had known

how to speak.

My understanding of this charming passage is that the image of two lovers, likened to the masts collapsed one against the other, implies that the ship depicted by Mpu Monaguna has two masts. Moreover, the lovers who are "unable to part" (tan wonan apasah) would probably be standing rather than sitting, and the legs of standing persons whose bodies are joined in embrace would remind the poet of bipod masts, which were typical for Indonesian pre-modern ships. The verbal form gumalangan in the second line of the stanza quoted above is difficult. In the corpus of Old Javanese literature, the verb gumalangain seems to be attested only in this passage. It is derived from the root form galangan, which exact meaning in Old Javanese is unknown. Zoetmulder (1982: 478), for one, glosses galangan as "1. sharpened bamboo pole; 2 . a bench or couch made of bamboo? a small pavilion of bamboo?" In the modern Javanese shipbuilding terminology, galaingai refers to the "dock," but its meaning in Old Javanese inscriptions seem to be "pavilion" or rather some kind of "prop"; it may be a technical word for a piece of wood or bamboo that secures some sort of a wooden construction and makes it permanent. My best guess is that galangan in the passage quoted above refers to the configuration of the two masts that collapsed one against the other, so that they "prop one another," which is how I translate the verb gumalaingan in the text. Another difficult term in this passage is tundan. Scholars of Old Javanese typically translate tundan as "deck," which is, however, rather anachronistic for before $1500 \mathrm{CE}$ boats were not yet provided with rigid decks. ${ }^{31}$ Zoetmulder (1982:

30. Sumanasāntaka 36.1. Old Javanese text taken from Worsley et al. (2013: 170). 31. The antiquity of boats with rigid decks in the Indo-Malay world is not known. 
2065) glosses tundan "storeyed construction (on chariot; decks or bridge of a ship); anything done in shifts (in succession); levy to be done in shifts?" In Sumanasāntaka 33.4 discussed above we have seen that boats denoted in Old Javanese banawa were provided with one or more tundan, a superstructure of an unknown form. The finding that Mpu Monaguna likens a banawa-boat provided with a tundan to the heron in flight would suggest that one tundan (one or more of them) would be positioned crosswise to the hull of the boat.

\section{The Seashore as a Place of Natural and Divine Beauty}

By far the most common depictions pertaining to the maritime side of preIslamic Java are the vignettes in which the seacoast is represented as a place of sheer natural beauty to be enjoyed. In these literary vignettes, the seacoast participates in what we can call "the economy of aesthetics": court-validated views and concepts according to which the (divinized nature) is subject to and participates in the refined court culture of show and performance of political power. The divinized nature thus takes part in a court pomp and show. At the same time, descriptions of the natural world are often eroticized, as we have seen above. Unlike in the previous sections, my treatment of this last theme must be very selective. Let us start with a charming passage in the Bhomantaka, where the beauty of the seacoast is compared to the beauty of a young woman:

\section{sawañ kanyā lwir nin pasisir i halilintan nropasuta \\ lə⿳亠丷厂̈n் warnanyāhyas mapata-patahan tan ryak alañö \\ layar nin banyāgā̄nusu-nusu katon manda tan awās \\ limut nin wway māwrāsəmu-sәти pupur pin̄hay i pipi ${ }^{32}$}

The seashore looked like a maiden as the prince passed by;

Her appearance was enchanting, all dressed up and with the lovely waves as her headband,

The sails of a merchant-ship resembled her breasts, faintly visible, not very clear, And the mist that spread on the water had the look of white powder on her cheeks. ${ }^{33}$

Elsewhere in the Sumanasantaka, we find another eulogy on the beauty of the sea and seacoast. Stanzas 51.1-2 is built upon a dialogue in which one of the court ladies tries to persuade Princess Indumati about the superiority of the charms of the seacoast. We have seen above that Indumati prefers the mountains to the pasisir coastal districts, which she considers dangerous

European ships were typically provided with rigid decks, but there is evidence that boats with permanent decks were known and used in Southeast Asia even before the first Europeans reached the region in the early sixteenth century. Such boats may have been denoted by the term kapal, a loanword from Tamil (Salmon 2019: 27).

32. Bhomāntaka 4.1. Old Javanese text taken from Teeuw and Robson (2005: 110).

33. Teeuw and Robson (2005: 111). 
and lacking a clearly established social hierarchy. The court lady, obviously well-informed about the visual beauty of the Javanese coast, opposes boldly Indumatī's views and tries to persuade her mistress to change her evaluation of the coast and people living there. Let me quote her words:
taham rakryan din parwata lowiha sanken jalanidhi anüșāpaṇ̃̂n rañkan் apasir asan்hub saha kilat muwah tan pāntyāntyāmpuhan ika bañun kārttika sadā manuknyāliwran yan wahu mari jawuh lwir laru-laru
kuməmban் tuñjun kāninan uwur-uwurnyānjrah aputih layar nin banyāgāanutakən añin añdoh kadi limut lə̀̇ə⿱亠巾 ryaknān sandhyāmirah asəmu meghānisik iwak laniit suñsañ lwirnya n maśaśadharamāyā makalañan ${ }^{34}$

"No my lady! How could the mountains possibly be superior to the ocean With its islands, creeping pandanus, beaches, mist, and lightning. And the endless surf. It is like an everlasting Kārttika."

"Like flowering lotuses caught by the wind white jellyfish are spread in all directions.

And the sails of ships running before the wind head off into the distance like mist. The waves are enchanting and in the evening are red and like clouds in the form of fish scales.

The sea with the moon's round reflection on it looks like the sky turned upside down. ${ }^{35}$

We have seen above that the images based on the topsy-turvy world were highly appreciated by Javanese kawis, who seem to have based this imagery on the actual Tantric practices documented in Old Javanese Tutur texts. Though Javanese kawi is typically seen as a "poet," in pre-Islamic times kawis were important religious figures, whose tasks are to be looked for especially in the field of warfare magic. Composing and writing kakawins was part of their ritual agenda. Zoetmulder speaks about "religio poetae," a practice that entailed teaching and religious duties particular to the social group of kawis. Multiple associations between the kawi, physical destruction, ruined temples, dead bodies, and the coastline, is most prominent in Sumanasāntaka 33.6-7. This textual sequence, in my view, one of the most charming descriptions of the seacoast in Asian literatures, informs us how a kawi comes to die at the place where a river empties into the sea, to be united there with the physical elements of the divinized nature:

34. Sumanasāntaka 51.1-2. Old Javanese text taken from Worsley et al. (2013: 206). 35. Worsley et al. (2013: 207). 
ramya lwir siluman karan் ri mukha nin் muhara paḍa-paḍ̄àhapit bañu

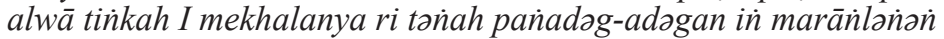
karwānunigul apāntaran sapan்uhuh kadi gupura siwak saken adoh lwir hambal sphațikāin alun turunan ì kawi pəjah atuhāìhañut lañö

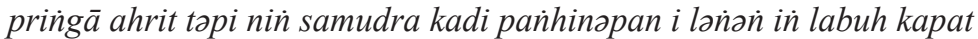
lwir prāsāda pukah karan் ni parañanya hana kadi silun்lun $i$ kawi airtamban்nya ban்un wwit in truh asəwö kilat awilat alün awankkawa lumrāwarṇa rənit kukusnya sinawat-sawat inidəran in guruṇạa ${ }^{36}$

The reefs, flanking the water on both sides at the river estuary, were like a vision conjured up

by magic.

These stretches of reef were broad and in their midst were places where those who came in the

pursuit of beauty stopped.

Both reefs, within shouting distance of each other, towered aloft, looking from afar like a split

gateway.

The sea swell resembled a flight of crystal steps, a staircase down which a poet descends when in old

age he dies and is swept away on a sea of poetic beauty.

The rugged and inaccessible terrain of the coastline was like a place to spend the night in the beauty

of the first rains of the fourth month.

The rocky cliffs there resembled a tower temple which was half tumbled down. It was like the

repository for the ashes of a poet.

Streams of water tumbling down were like the roots of misty drizzle, which put forth shoots of

lightning, twisting and reaching out, creating a luminous glow in the sky.

The spray spread out on all sides like small flies upon which the circling cliffswallows swooped. ${ }^{37}$

\section{Conclusion}

This study has discussed selected passages from a number of Old Javanese kakawin court poems in which the sea, seacoast, and the life associated with this environment is depicted. Unlike in the much better studied classical Malay literature, authors of kakawins were little interested in the theme of the open seas, but they demonstrate some interest in the natural, social, and economic life of the seacoast. In most literary vignettes analysed in this study, depictions of the seacoast are clearly based on the rugged coastline of south Java, where the sea is deep and cliffs and small islands often represent remarkable landscape features, rather than mostly flat coasts of north Java

36. Sumanasāntaka 33.6-7. Old Javanese text taken from Worsley et al. (2013: 168). 37. Worsley et al. (2013: 169). 
bordered by the shallow Java Sea. Three topics were discussed in some detail: the fishing folk inhabiting the world of kakawin, boats and ships noted by ancient Javanese poets (special attention has been paid to Old Javanese terms sambo and jón), and the natural beauty of the coastline celebrated in several texts. I have also analysed a unique passage in the Bhomãntaka, in which a harbour and its economy is depicted in a remarkable narrative detail. To conclude, Old Javanese audience, based mostly at inland royal and princely courts, considered the seacoast to be a dangerous, yet beautiful place, where whales can be spotted easily, and where egalitarian fishermen and mariners, little interested in court hierarchies, plied their trade. Literary vignettes discussed in this study certainly demonstrate that Javanese poets were well-aware and knowledgeable of the life in seacoast districts, and were able to depict their socio-cultural environment with a distinct charm and often surprising attention to detail. We can only regret the almost complete loss of the Old Javanese literary output of the pasisir districts predating $1500 \mathrm{CE}$. As a consequence, the social, economic, and religious life of Javanese preIslamic ports and early cities remains just little known.

\section{References}

van Aelst, A. 1995. "Majapahit picis: the currency of a 'moneyless' society, 1300-1700," Bijdragen tot de Taal-, Land-en Volkenkunde 151(3): 357-393.

Barrett Jones, A.M. 1984. Early Tenth Century Java from the Inscriptions: A Study of Economic, Social and Administrative Conditions in the First Quarter of the Century. Dordrecht/ Cinnaminson: Foris Publications.

Braginsky, Vladimir. 2004. The heritage of traditional Malay literature: a historical survey of genres, writings and literary views. Leiden: KITLV.

Creese, Helen. 2004. Women of the kakawin world; Marriage and sexuality in the Indic courts of Java and Bali. Armonk, NY: Sharpe.

de Casparis, J.G. 1988. "Where Was Pu Sinḍok's Capital Situated?," in: H.I.R. Hinzler (ed.), Proceedings Studies in South and Southeast Asian Archaeology. Leiden: Kuntji Press: 39-52.

Hoogervorst, Tom. 2013. Southeast Asia in the Ancient Indian Ocean World; Combining Historical Linguistics and Archaeological Approaches. Oxford: Archaeopress.

Hoogervorst, Tom, and Jiri Jákl. 2020. "The Rise of the Chef in Java," Global Food History 6(1): 3-21.

Ják1, Jiri. 2014. “The whale in Old Javanese kakawin literature: timingila, 'elephant fish', and lombwara terms revisited," Pandanus 14(2): 103-118.

Ják1, Jiri. 2016. "The Folding Book Format (Concertina) in Pre-Islamic Java: Revisiting the Old Javanese Term Ləpihan,” Bulletin de l'École française d'Extrême Orient 102: 165-193.

Jákl , Jiri and Hoogervorst, Tom. 2017. "Custom, Combat, and Ceremony: Java and the IndoPersian Textile Trade," Bulletin de l'École française d'Extrême-Orient 103: 207-235.

Jahan, Shahnaj Husne. 2006. "Re-examining 'Borobudur Ships' as Evidence of Maritime Contact with South Asia," in: Adalbert Gail, Gerd J.R. Mevissen, and Klaus Bruhn (eds.), Vanamālā: Festschrift A.J. Gail. Berlin: Weidler Buchverlag: 78-86. 
Lieberman, Victor. 2009. Strange Parallels; Southeast Asia in Global Context, c. 800-1830. Volume 2. Mainland Mirrors: Europe, Japan, China, South Asia, and the Islands. Cambridge: Cambridge University Press.

Manguin, P.-Y. 1980. "The Southeast Asian Ship: An Historical Approach," Journal of Southeast Asian Studies 11(2): 266-276.

Manguin, P.-Y. 1993. "The vanishing jong: insular Southeast Asian fleets in trade and war (fifteenth to seventeenth centuries)," in: Reid, A. (ed.), Southeast Asia in the Early Modern Era: Trade, Power, and Belief. Ithaca: Cornell University: 197-213.

Manguin, P.-Y. 1996. "Southeast Asian Shipping in the Indian Ocean during the First Millennium A.D.," in: Himanshu Prabha Ray and Jean-François Salles (eds.), Tradition and Archaeology. Early Maritime contacts in the Indian Ocean. Proceedings of the International Seminar Techno-Archaeological Perspectives of Seafaring in the Indian Ocean $4^{\text {th }}$ cent. BC-1 $5^{\text {th }}$ cent. A.D. New Delhi, 28 Feb-4 March. New Delhi, Manohar: 181-198.

Manguin, Pierre-Yves. 2010. "The Ships on the Borobudur Reliefs," in: John N. Miksic, Noerhadi Magestari, Jan Fontein, Timbul Haryono, and Idham Bachtiar (eds.), Borobudur: majestic, mysterious, magnificent. Yogyakarta: Taman Wisata Candi Borobudur, Prambanan \& Ratu Boko: 180-185.

Manguin, Pierre-Yves. 2012. "Lancaran, Ghurab and Ghali: Mediterranean Impact on War Vessels in Early Modern Southeast Asia," in: Geoff Wade and Li Tana (eds.), Anthony Reid and the Study of the Southeast Asian Past. Singapore: ISEAS Publishing: 146-182.

Porée-Maspero, E. 1986. "Jonques et po, sampou et sampan.” Archipel 32: 65-85.

Pou, Saveros. 1992. Dictionnaire Vieux Khmer-Français-Anglais / An Old Khmer-FrenchEnglish Dictionary. Paris: Editions Cedoreck.

Prihatmoko, Hedwi. 2014. "Transportasi Air Dalam Perdagangan Pada Masa Jawa Kuno di Jawa Timur (Water Transportation in Trade in East Java during Ancient Java Period)," Forum Arkeologi 27(3): 155-174.

Robson, S.O. 2012. "Imagery of the temple in Old Javanese poetry," in: Alexandra Haendel (ed.), Old Myths and New Approaches; Interpreting Ancient Religious Sites in Southeast Asia. Melbourne: Monash University: 252-266.

Robson, S.O. 2015. The Old Javanese Rāmāyana; A new English Translation with an Introduction and Notes. Tokyo: Research Institute for Languages and Cultures of Asia and Africa, Tokyo University of Foreign Studies.

Robson, S.O. 2016. The kakawin Ghațotkacāśraya by Mpu Panuluh. Tokyo: Research Institute for Languages and Cultures of Asia and Africa, Tokyo University of Foreign Studies.

Salmon, Claudine. 2019. "Contact Languages on the South China Sea and Beyond $\left(15^{\text {th }}\right.$ $18^{\text {th }}$ Centuries)," Asian Culture 43: 20-43.

Schottenhammer, Angela. 2012. "The 'China Seas' in world history: A general outline of the role of Chinese and East Asian maritime space from its origins to c. 1800," Journal of Maritime and Island Cultures 1: 63-86.

Setianingsih, R.M. 1993. "Perahu Dalam Beberapa Prasasti Indonesia," Berkala Arkeologi 13(1): 10-21.

Supomo, Suryo. 1995. "Indic Transformation: The Sanskritization of Jawa and the Javanization of the Bharata," in P. Bellwood, J.J. Fox and D. Tryon (eds). The Austronesians: Historical and Comparative Perspectives. Canberra, Australian National University: 309-332.

Teeuw, A. and S.O. Robson. 2005. Bhomāntaka; The death of Bhoma. Leiden: KITLV Press. 
Thompson, Carl (ed.). 2013. Shipwreck in Art and Literature; Images and Interpretations from Antiquity to the Present Day. London: Routledge.

Wiryamartana, I. Kuntara. 1992. "The 'sea' in Old Javanese literature," in: V.J.Houben, H.M.J. Maier, and W. van der Molen (eds.), Looking in odd mirrors; The Java sea. Leiden: Vakgroep Talen en Culturen van Zuidoost-Azië: 97-111.

Wisseman Christie, J. 1995. "State formation in early maritime Southeast Asia: A consideration of the theories and the data," Bijdragen tot de Taal-, Land- en Volkenkunde 151(2): 25-88.

Wisseman Christie, J. 1996. "Money and Its Uses in Javanese States of the Ninth to Fifteenth Centuries A.D.," Journal of the Economic and Social History of the Orient 39(3): 243-286.

Wisseman Christie, J. 1998. "Javanese Markets and the Asian Sea Trade Boom of the Tenth to Thirteenth Centuries A.D.," Journal of the Economic and Social History of the Orient 41(3): 344-381.

Worsley, Peter. 2012. "Journeys, palaces, and landscapes in the Javanese imaginary; Some preliminary comments based on the kakawin Sumanasāntaka," Archipel 83: 147-171.

Worsley P., S. Supomo, T. Hunter \& M. Fletcher (2013). Mpu Monaguna's Sumanasāntaka: An Old Javanese epic poem, its Indian source and Balinese illustrations. Leiden/Boston: E. J. Brill.

Zoetmulder, Piet J. 1974. Kalangwan: A survey of Old Javanese Literature. The Hague: Martinus Nijhoff.

Zoetmulder, Piet J. 1982. Old Javanese - English dictionary (with the collaboration of S.O. Robson). 's-Gravenhage: Martinus Nijhoff. 2 vol. 